\title{
Delineating shallow Neogene deformation structures in northeastern Pará State using Ground Penetrating Radar
}

\author{
DILCE F. ROSSETTI
}

\author{
Museu Paraense Emílio Goeldi, Coordenação de Pesquisas e Pós-Graduação
}

Cx. Postal 399, 66077-530 Belém, PA, Brasil

Manuscript received on March 26, 2002; accepted for publication on March 7, 2003; presented by ALCIDES N. SIAL

\begin{abstract}
The geological characterization of shallow subsurface Neogene deposits in northeastern Pará State using Ground Penetrating Radar (GPR) revealed normal and reverse faults, as well as folds, not yet well documented by field studies. The faults are identified mostly by steeply-dipping reflections that sharply cut the nearby reflections causing bed offsets, drags and rollovers. The folds are recognized by reflections that are highly undulating, configuring broad concave and convex-up features that are up to $50 \mathrm{~m}$ wide and 80 to $90 \mathrm{~ns}$ deep. These deformation structures are mostly developed within deposits of Miocene age, though some of the faults might continue into younger deposits as well. Although the studied GPR sections show several diffractions caused by trees, differential degrees of moisture, and underground artifacts, the structures recorded here can not be explained by any of these "noises". The detailed analysis of the GPR sections reveals that they are attributed to bed distortion caused by brittle deformation and folding. The record of faults and folds are not widespread in the Neogene deposits of the Bragantina area. These GPR data are in agreement with structural models, which have proposed a complex evolution including strike-slip motion for this area from the Miocene to present.
\end{abstract}

Key words: Neogene, northeastern Pará State, Ground Penetrating Radar, tectonics, sedimentary rocks.

\section{INTRODUCTION}

There are numerous works illustrating the application of Ground Penetrating Radar (GPR) to increase stratigraphic and facies data collection in shallow surface throughout the world (e.g., Bridge et al. 1995, Stephens 1994, Bristow 1995, Van Heteren et al. 1998, Dagallier et al. 2000). In particular, this methodology has been successfully applied for mapping of facies and stratigraphic surfaces of Neogene deposits in northeastern Pará State, providing more detailed information to reconstruct the deposi-

Correspondence to: Dilce F. Rossetti

E-mail: rossetti@museu-goeldi.br tional environments and understand their evolution through time (Rossetti and Góes 2001 a,b,c, Fig. 1). The GPR experiments conducted in this area have led to image some intriguing features recorded by reflection distortions, which are the subject of this paper. It is well known that the interpretation of GPR profiles might be biased due to diffractions caused by above-ground objects (trees, metallic fences, power lines, buildings, etc.), as well as buried objects (e.g., underground utility lines, storage tanks), and even differences in moisture (Roberts et al. 1991, Asprion 1998, Bano et al. 2000). These elements might cause noises and interfere with true reflec- 
tions, representing a major problem during GPR interpretation. The reflection distortions observed in the study area can not be attributed to noises, but reflect more probably tectonic deformation. The record of faults and fractures in Cenozoic deposits of the Bragantina Zone is not new (Katzer 1933, Ackermann 1964). Tectonic models combining normal and strike-slip faults have been proposed for this area (Igreja et al. 1990, Costa et al. 2001). These studies are mostly based on the analysis of drainage systems and morphological aspects of coastal cliffs, while geological field evidence remains inadequate to test the models. Actually, the available outcrops, mostly including isolated coastal cliffs and limestone quarries, show dominantly horizontal deposits, though bed tilting in the order of $20^{\circ}$ to $60^{\circ}$ has been also reported (Costa et al. 1993). The GPR revealed to be a technique of great use to prospect subsurface fault and fracture segments in Neogene deposits of the Bragantina Zone. It also helped to reveal features that suggest the presence of folds, not yet recorded in these deposits. Based on the results obtained in this investigation, the use of GPR provides an alternative technique for imaging large-scale deformation structures in shallow Neogene deposits in northeastern Pará State, improving the knowledge of its tectono-sedimentary history.

\section{MATERIALS AND METHODS}

The GPR operates with emission of high frequency (10 to $2500 \mathrm{Mhz}$ ) electromagnetic waves in the ground for detecting material variations. Several papers discuss in detail the basic theory of GPR (e.g., Moffat and Puskar 1976, Fisher et al. 1992, Asprion 1998). The GPR system used in this field survey was a Geophysical Survey Systems, Inc. Model SIR-2, with monostatic antenna of $200 \mathrm{Mhz}$ frequency and slow walking pace. The system uses a $12-\mathrm{V}$ battery, and it was run in a continuous recording mode, with a two-way travel time setting averaging $150 \mathrm{~ns}$ with 512 samples per scan. Although Common Mid Point tests were not carried out in the study area, calibration with outcrop data led to an estimated depth in- vestigation of $12 \mathrm{~m}$. Horizontal surface control was made by the addition of markers every $50 \mathrm{~m}$ during data acquisition. The sections presented in this paper did not require topographic correction, given the flat nature of the study area at the sea level. To improve the image quality, the GPR profiles were analyzed using a RADAN software with the least processing including gain correction and application of filters with Finite Impulse Response to remove bands of ringing and high frequency ("snow") noises and to enhance low frequency reflections. The same filters were used in all GPR profiles illustrated in this paper in order to allow a comparison of GPR facies characteristics.

\section{GEOLOGICAL BACKGROUND}

The Bragantina Zone is located in an area that has been undergone to a complex tectonic deformation since the initial continental break up in the Early Cretaceous that culminated with the origin of the South Atlantic Ocean. The area is bounded by the Marajó Graben System to the northwest and west, the Bragança-Viseu and São Luís-Grajaú Basin to the southeast, and the Pará-Maranhão Platform to the north. Although it represents a stable area compared to the strongly extended and strike-slip deformed adjacent areas, studies have shown that the Bragantina Zone had also a complex tectonic evolution through the Tertiary and on (Igreja et al. 1990, Costa et al. 1993). According to these authors, two sets of features characterize this area: northeast dipping normal faults developed during Late Tertiary; and northeast-southwest and east-west strikeslip faults linked by northwest-southeast normal faults of Pleistocene to Holocene age.

Previous studies combining fieldwork with GPR data has helped to improve our knowledge related to the paleoenvironmental and stratigraphic framework of Neogene deposits in northeastern Pará State and to analyze them within the context of sea level changes (Rossetti et al. 1989, 1990, Rossetti 2001, Rossetti and Góes 2001 a,b,c). Mapping of regional unconformities has led to propose three depo- 


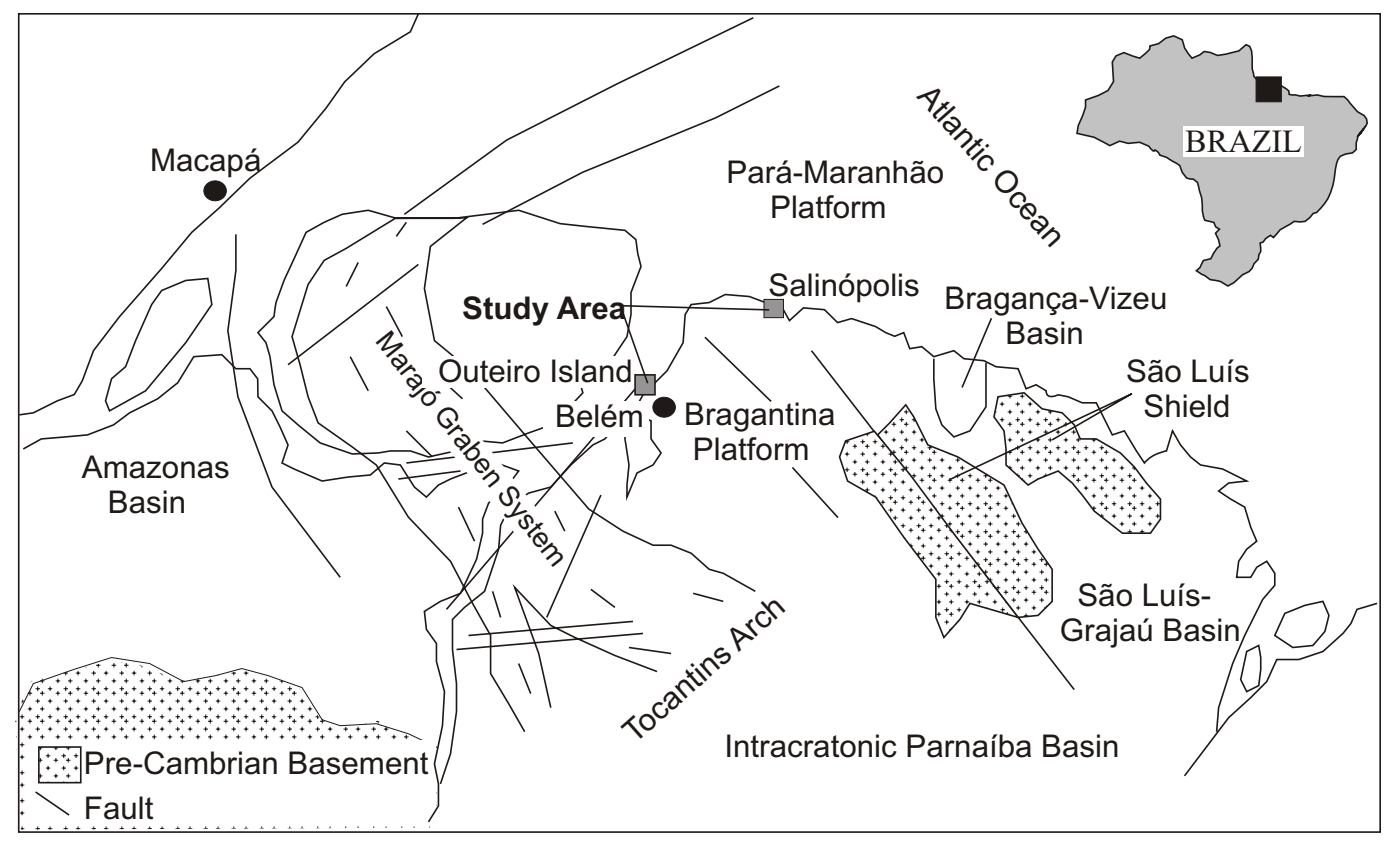

Fig. 1 - Location map of the study area in northeastern Pará State, Brazil. The two boxes indicate the areas of the Bragantina Zone where shallow Neogene deposits have been imaged using GPR.

sitional sequences for these deposits (Rossetti 2001, Fig. 2). Sequence A (corresponding to the Pirabas Formation and lowermost portion of Barreiras Formation) consists of a mixed carbonate-siliciclastic unit of late-Oligocene to early Miocene age, and include gray to yellowish, massive limestones (biocalcirudite, biocalcarenite, biohermite, calcirudite, micrite) interbedded with black, gray and greenish, laminated mudstones, and minor calcareous sandstones. These deposits were deposited in environments ranging from transitional marine to restricted shelf. Sequence B (middle to upper portions of the Barreiras Formation) consists of variegated, nonfossiliferous, siliciclastic deposits including conglomerate, sandstone and claystone, which were formed in an estuarine setting during the Middle Miocene (e.g., Rossetti 2001). Sequence C (PostBarreiras Sediments), of an uncertain age younger than Pliocene, consists of fine-grained, massive sandstones and mudstones attributed to eolian coastal dunes and embayments. Recent studies have led to propose that the latter might include at least three stratigraphic units that record a complex history of sedimentation versus erosion during the latest Neogene (Rossetti et al. 2003).

Correlation between late Cenozoic units from northeastern Pará State and temporally equivalent deposits located approximately $600 \mathrm{~km}$ of distance in the São Luís-Grajaú Basin, Maranhão State, has led to a refined history of sea level changes for northern Brazil (Rossetti 2000). According to this reconstruction, successive drops in relative sea level have produced unconformities that bound second-order depositional sequences formed mainly during periods of transgression to highstand (Fig. 2). Whether by eustasy or tectonic movement, or by a combination of the two, the cause of these sea level fluctuations remains open.

\section{RADAR STRUCTURES}

The GPR data acquisition in northeastern Pará State has surveyed Neogene sedimentary successions from two areas so far: the Outeiro Island and the Atalaia area in the district of Salinópolis (Fig. 1). The 


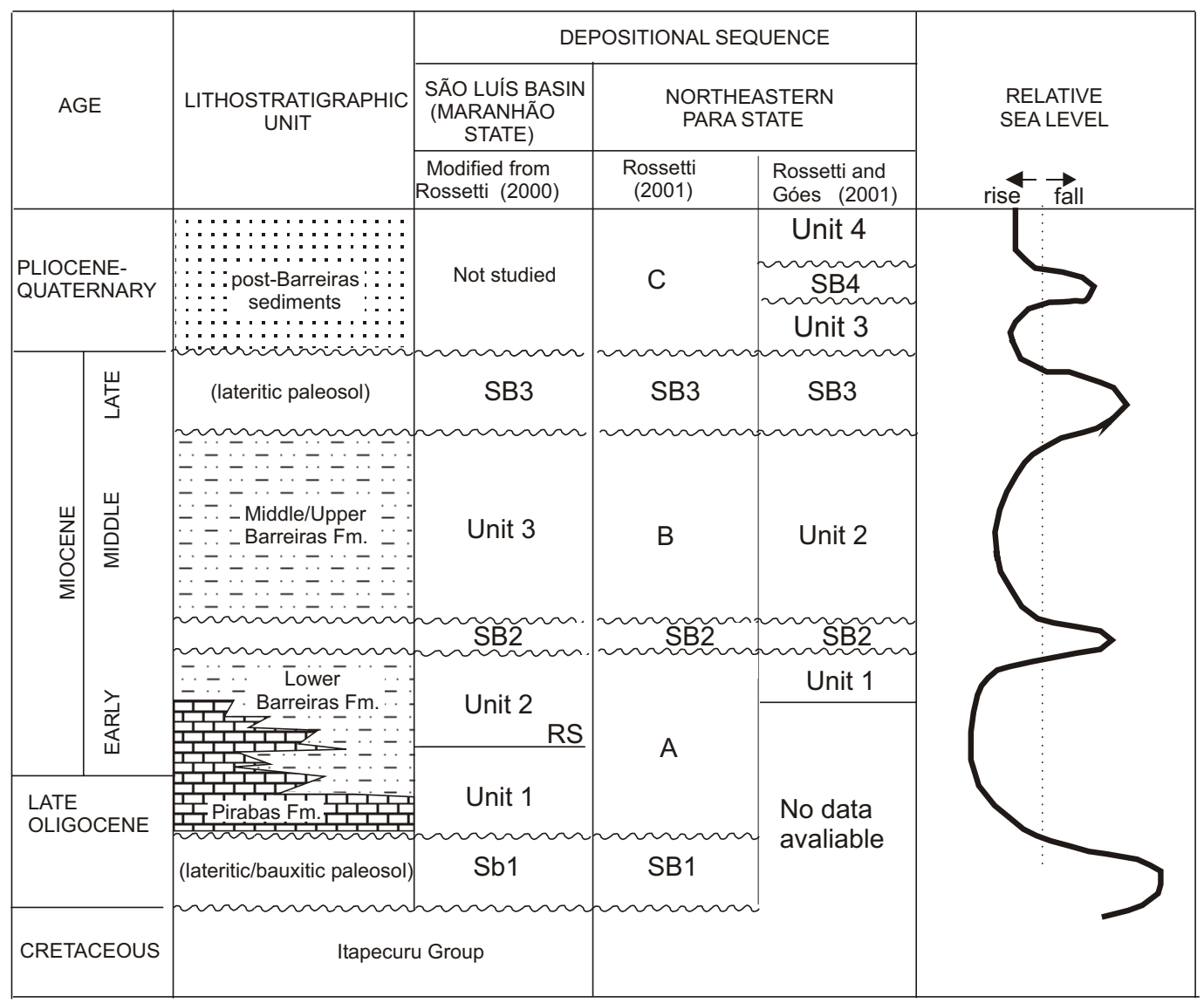

Fig. 2 - Summary of the stratigraphic framework during the Cenozoic of the Bragantina Zone, State of Pará, and its correlation with the units exposed in northern São Luís-Grajaú Basin, Maranhão State. The last column to the right illustrates the suggested relative sea level history proposed for the north of Brazil. (Modified from Rossetti et al. 2003).

volume of data collected in these places reaches now up to $15 \mathrm{~km}$ of continuous profiling, which has been crucial to provide a 3-dimensional view of facies architecture and stratigraphic framework at shallow depths up to $15 \mathrm{~m}$. A discussion about these issues is beyond the objective of this study and those interested should refer to references presented elsewhere (Rossetti and Góes 2001 a,b, c, Rossetti et al. 2003).

In addition to help understanding the stratigraphy and paleoenvironments, the available GPR sections have allowed the identification of several styles of reflection distortions. Among these, hyperbolic reflections, for instance caused by underground artifacts, pebbles or large rock fragments, are common, as are reflection distortions due to the influence of trees or moisture below surface ponds, which are readily deciphered with basis on field observations. However, also detectable are some intriguing, large-scale disturbances that show characteristics conforming with true bed deformation including fractures, faults and folds, rather than reflection "noises". There are several GPR records of faults in literature (e.g., Smith and Jol 1995, Stevens et al. 1995, Toshioka et al. 1995, Busby and Merritt 1999, Bano et al. 2000, Overgaard and Jakobsen 2001) and the criteria used for their identification were summarized in Wyatt and Temples (1996), including: abrupt reflection terminations; direct fault plane reflections; diffractions at reflection terminations; presence of dragging and rollovers of strata; 
correlation of reflectors across a fault plane; and loss of coherency beneath a fault plain or distorted dips seen through the fault plane. The GPR signature of folds is scarce, but an example has been recorded from Quaternary of west Cumbria, UK (Meschede et al. 1997, Busby and Merritt 1999). Similar features were identified in the Neogene deposits prospected in the shallow surface of northeastern Pará, as described in the following.

\section{FAUlts and Fractures in GPR Sections}

Numerous reflection distortions were identified in the GPR images collected in the Bragantina Zone, which are better related to faults and fractures. Figures 3 A-D show two laterally correlatable profiles located approximately $15 \mathrm{~m}$ apart with several inclined reflection segments. These show an apparent high angle, which is due to the vertical exaggeration of the radar sections. Some of these inclined segments consist of white, reflection-free lines defined by sharp interruptions of the surrounding flat lying beds. These dipping lines may separate flat lying reflections that show offsets. This is particularly well illustrated between 20 and $40 \mathrm{~m}$ of horizontal distance, where the reflections step down to the right as it passes through a steeply dipping reflection. The reflections in both sides of this feature are bent, forming convex and concave-up features in the left and right side of it, respectively. Two concave shapes between 40 and 80 ns of depth are mantled by downlapping sigmoidal reflectors. Noteworthy is the progressive downward increase in reflection offset, which reaches up to $40 \mathrm{~ns}$ (estimated $3 \mathrm{~m}$, considering calibration with outcrops) at the base of the section (arrows). In the right section, there is a discontinuity surface bounding underlying, steeply dipping reflections and overlain by sharp reflections that terminate against it in onlap. Deciphering the nature of all the steeply dipping reflections is not so simple as they may record different situations. For instance, the reflections bounded by the discontinuity surface in the right section could be interpreted as bed deformation at the edge of a cliff. Correlation of this discontinuity surface throughout sev- eral square kilometers suggests it to be an important stratigraphic marker that corresponds to the unconformity at the end of the Miocene. The reflection distortion between 20 and $40 \mathrm{~m}$ is, on the other hand, securely attributed to a normal fault, with the hanging wall to the right and foot wall to the left. The downward increase in reflection offset attests to an upward decrease in fault activity through time. As the fault process took place, the beds on the foot wall were slightly dragged to accommodate the displacement. The sigmoidal reflectors that downlap the concaveup features between 40 and $80 \mathrm{~ns}$ of depth suggest that sedimentation might have been affected, causing a change in sedimentary patterns. The other inclined reflections seen throughout the sections might have been caused by faults with smaller offsets, not detectable by the GPR resolution, or even fractures.

The example shown in figure 4 illustrates Middle/Late Miocene deposits, represented by units 1 and 2, which are unconformably overlain by units 3 and 4, developed from the Pliocene and corresponding to the post-Barreiras sediments. The reflections in this section are locally disturbed in its left side, as revealed by the slight downward displacements of the stratigraphic surfaces between units 2 and 3 and units 3 and 4 . The reflection disturbance at this point is also indicated by the dragging of reflections within unit 2, which is attributed to parallel-laminated mudstones. The reflection pattern observed at this locality is better explained by a southwest-dipping normal fault, which cuts through unit 2. The upward fault continuity into unit 3 as indicated in figure 4 is one possibility to explain the displacement of unit 3 , but the corresponding deposits in the right left of the fault could also represent colluvial deposits. Because reflection resolution decreases substantially in the lower part of the section, determination of fault continuity into these beds was precluded. For this same reason, it is problematic to interpret the strong reflector indicated as the top of unit 1 . In fact, the top of this unit is very planar, which at first suggested ground water level, but calibration with outcrop data at a cliff face showed it to match with a transgressive surface at the top of tidal-dominated heterolithic de- 

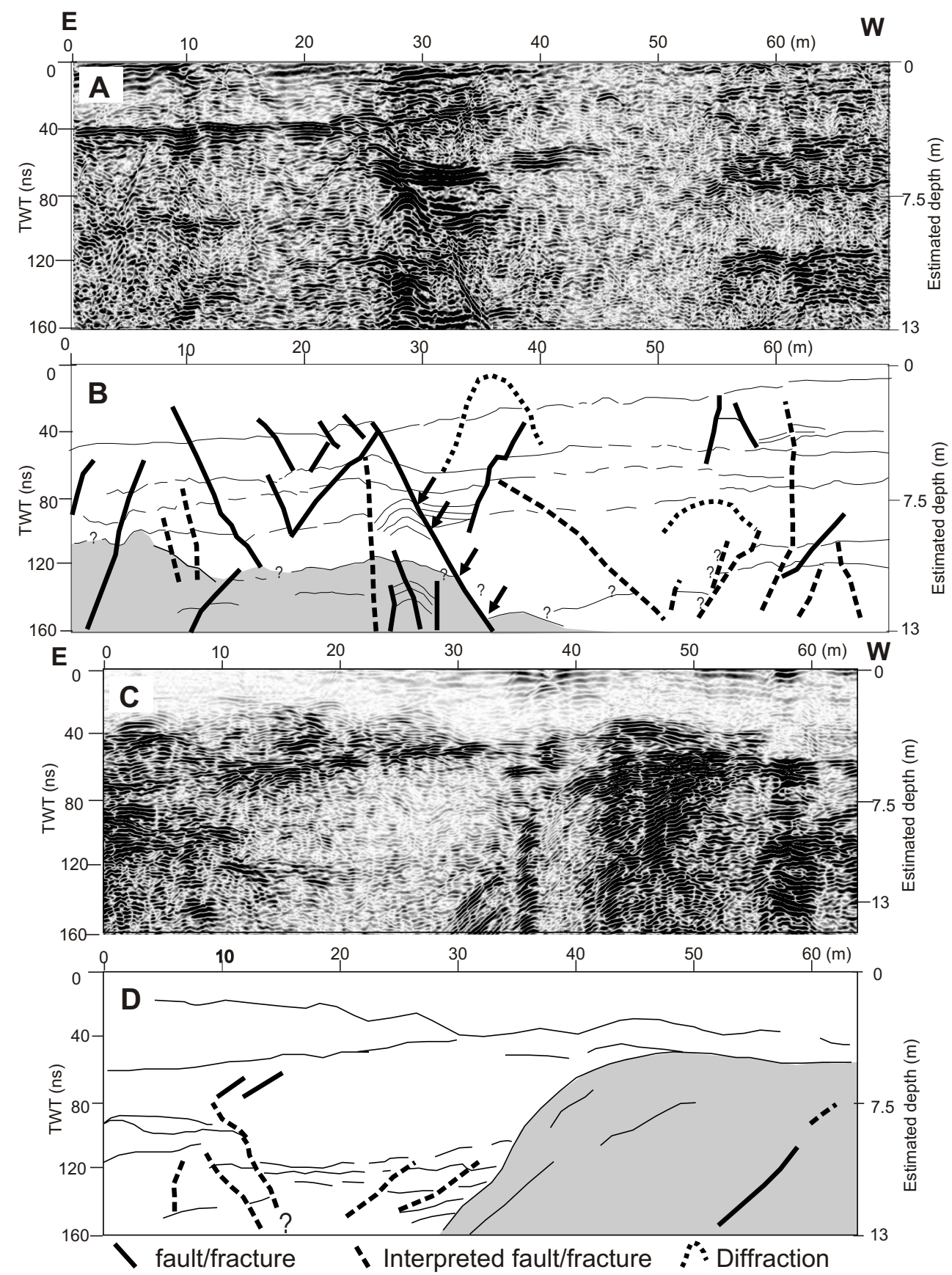

Fig. 3 - A,C) GPR and B,D) interpreted line drawings of sections from the Atalaia Beach, illustrating numerous steeply dipping faults and fractures. The gray area in B and D indicates deposits of Miocene age. Note that the faults/fractures are not confined to these deposits. Observe also a pronounced normal fault (A and B), with drags of the reflections along the fault plane (arrows). The Miocene deposits are thicker in the section to the right, as they stand up forming a feature suggestive of a buried cliff. See text for further explanations. (Modified from Rossetti and Góes 2001 a,b,c). 


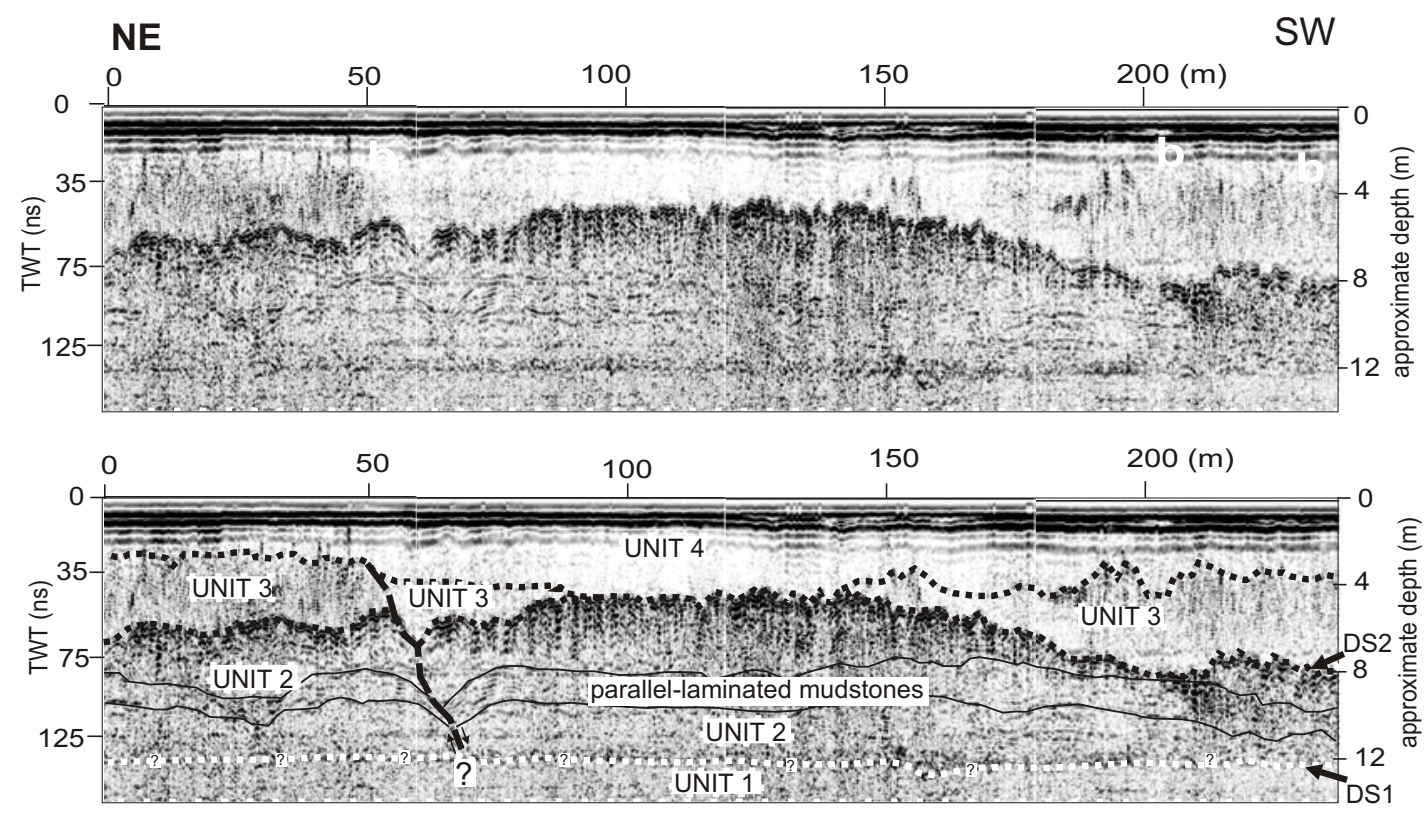

Fig. 4 - Non-annotated (upper) and annotated (lower) GPR section from the Outeiro Island area, illustrating four stratigraphic units (units 1 to 4) bounded by unconformities (hatched lines) that are locally displaced by a steeply-dipping normal fault (inclined black line). Note the drag of parallel reflections attributed to laminated mudstones from stratigraphic unit 2 . Radar resolution does not allow determining the continuity of this fault down into unit 1 , neither its upper boundary. The white dotted line indicates a trace that looks like ground water table, but outcrop data in the cliff face indicates this to match with a transgressive surface at the top of heterolithic deposits from unit 1 . Units 1 and $2=$ Miocene age (Barreiras Formation); Units 3 and $4=$ Pliocene and younger (post-Barreiras sediments). See text for further explanations.

posits of Unit 1 (Rossetti 2001). The outcrop data at this place also show several strata deformation features, which is consistent with the GPR interpretation provided in this paper.

The sections illustrated in figure 5 help to support the presence of faults and fractures in the Neogene of the Bragantina Zone. Four stratigraphic units are present, which correspond to the Pirabas/ Barreiras succession (two lower ones, with chaotic reflections) and the post-Barreiras (Pliocene and younger deposits with relatively more discontinuous parallel reflections). A strong reflector in the lower, right corner of the section is possibly due to calcareous rocks, typical of the Pirabas Formation. Based on comparisons with field data (Rossetti 2000, 2001), the strong reflectors that mark the top of the lowermost unit (indicated by a set of black arrows in Fig. 5) are attributed to iron cementation and/or soil formation. The top of the Miocene traced at near $36 \mathrm{~ns}$ in the left side of the sections, is rapidly lowered down to $80 \mathrm{~ns}$ of depth through a short horizontal distance between 35 and $55 \mathrm{~m}$. Several drags and rollovers might be distinguished in this interval. In addition to the sudden reflection offset, this interval in the middle of the section shows a series of other parallel, steeply dipping lines that disrupt the nearby reflections, resulting in less pronounced offsets, as well as drags and rollovers, or even both. Also note, in the right corner of the section, a relatively more depressed segment at the top of the Miocene unconformity, which is underlain by short, steeply dipping reflectors, and is overlain by reflections that change upward from slightly concave to parallel. Interpretation of GPR sections revealed 

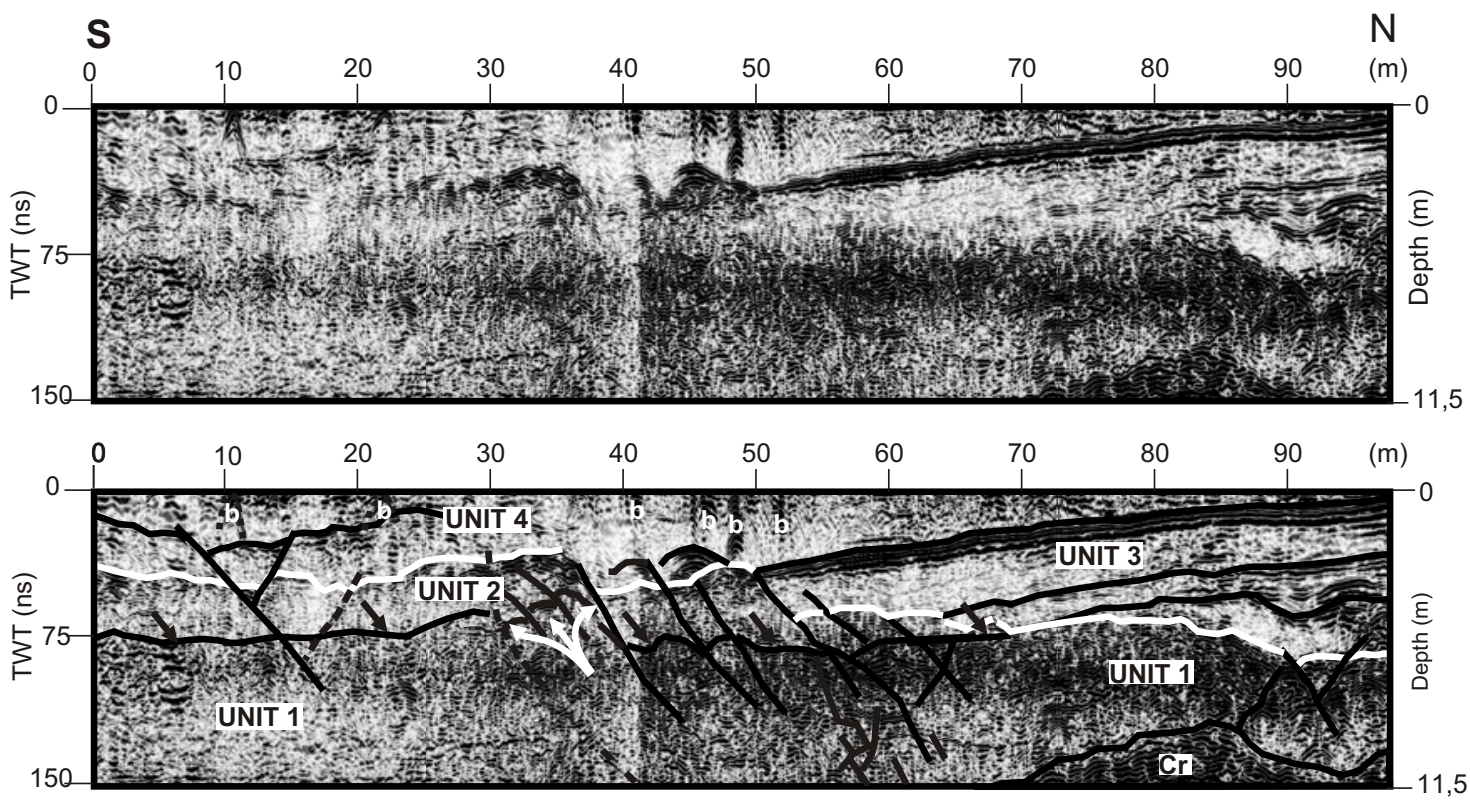

Fig. 5 - Non-annotated (upper) and annotated (lower) GPR section from the Atalaia Beach area, illustrating deposits correlatable to the Miocene (below white line) with reflections strongly disrupted by faults (continuous inclined black line = fault; hatched inclined black line $=$ possible fault; white arrow $=$ inverse fault; set of arrows above unit $2=$ possible paleosoil horizon cemented by iron; $b=$ large boulder/cobble or man artifacts; $\mathrm{Cr}=$ calcareous rocks). See text for further explanations.

both normal and reverse faults. As the beds were disrupted, the faulted blocks moved down toward the right side of the section, increasing subsidence and thus creating space to accommodate sediments that are not present in the left side of the section. The more pronounced depressed segment at the right corner seems to record a sector with relative increased subsidence caused by fault activity, where the postBarreiras sediments have the largest thickness.

\section{FOLDS}

In addition to faults and fractures, a complex type of reflection distortion is observed in the GPR sections studied in the northeastern of Pará State. This includes reflections that appear strongly undulating, forming broad concave and convex up shapes that are up to $50 \mathrm{~m}$ wide and 80 to $90 \mathrm{~ns}$ deep. These features bound a series of internal reflections that are also undulating, conforming with the external concave and convex up shapes. Three figures were selected to illustrate these structures. Figure 6 shows a syncline and an anticline in the right side of the section. The left margin of the syncline, which shows several inclined reflections attributed to fractures and faults, ends abruptly forming a wedge that pinches out around $40 \mathrm{~ns}$ of depth. In addition, the lower boundary of the wedge is a sharp inclined reflection that truncates all the underlying reflections. The undulated interval is sharply bounded upward (between 65 and $75 \mathrm{~ns}$ of depth) by a package of high frequency, chaotic reflections that are in sharp contrast with the overlying lower frequency reflections that terminate in onlap against it. The top chaotic reflections are correlatable with an unconformity at the top of the Miocene deposits in the study area, which is marked by a paleosol with lateritic concretions that probably justify the distinguished high frequency interval. Noteworthy is that the strata above this unconformity are almost not deformed.

Figure 7 illustrates five stratigraphic intervals with the top of interval 3 correlatable with the upper boundary of the Miocene deposits. Similarly to 


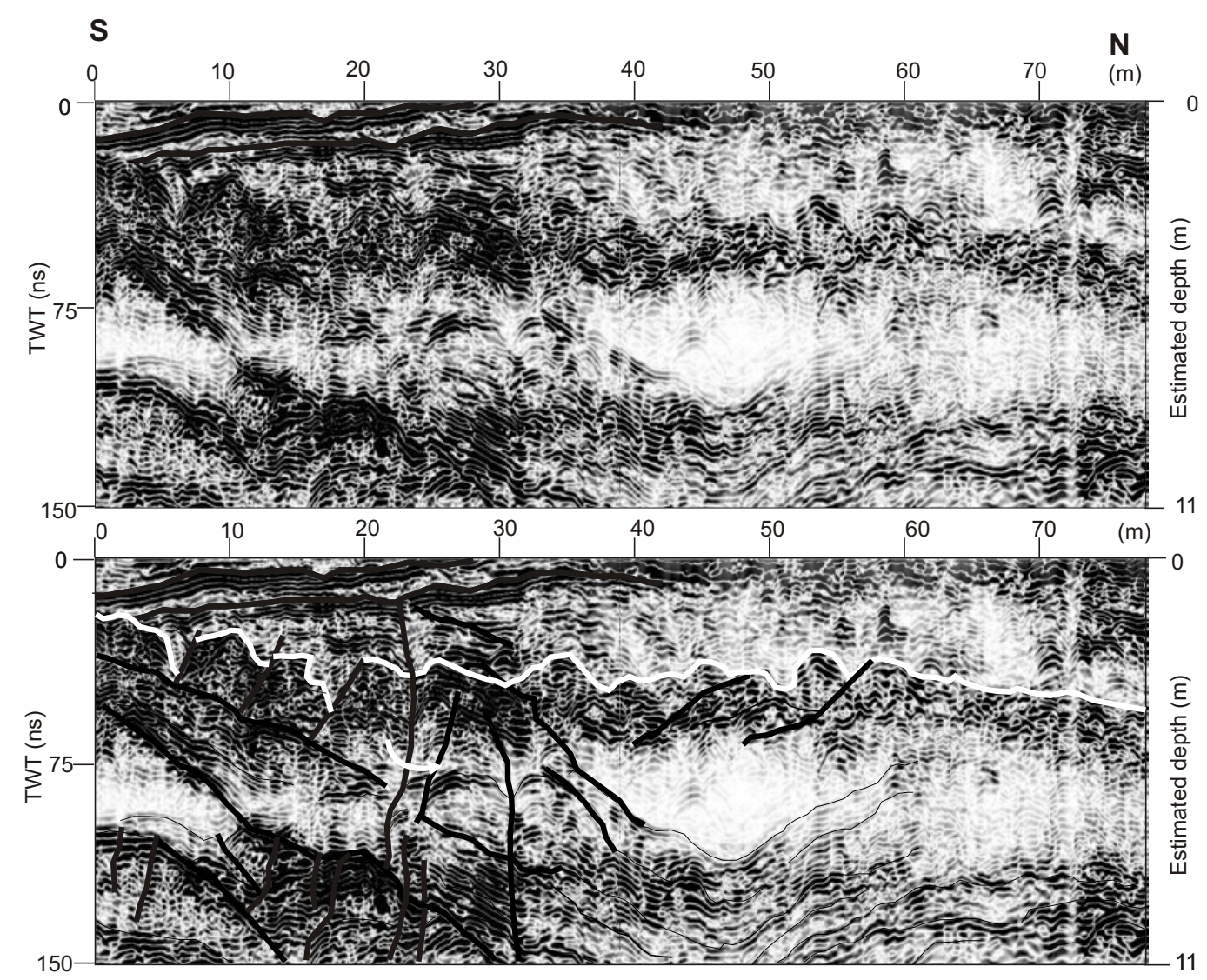

Fig. 6 - Non-annotated (upper) and interpreted (lower) GPR sections from the Atalaia Beach, where deposits of Miocene age (below white line) are strongly deformed by both folds and faults. Normal and reverse (white arrow) faults are present. Note that the degree of deformation decreases substantially upward, where only a few faults can be distinguished.

the previous figure, the undulating reflections occur below this level, being particularly well developed in units 1 and 2 where two anticlines with an associated syncline are observed in the pattern. The overlying unit 3 was not affected by deformation, showing some parabolae, attributed to the presence of large boulders or cobbles. It is interesting to notice the sharp contact between unit 3 and the underlying convex anticline in the left side of the section, which suggest erosional truncation.

A horizon with highly undulating reflections configuring concave and convex shapes is also well illustrated in the lower portion of figure 8 . As seen in the previous figures, the internal reflections clearly follow the external shapes. In this instance, the un- dulations reach up to $90 \mathrm{~ns}$ in height (nearly $7 \mathrm{~m}$ ) and have a wavelength of up to $50 \mathrm{~m}$ of horizontal distance. A number of faults, mostly sub-vertical to vertical disrupt the internal reflections, particularly at the anticline apex. Some of these faults continue upward. Noteworthy is that the reflections overlying these undulating reflections show a different pattern, grading upward from low frequency, discontinuous to chaotic reflections, then to more horizontal reflections that are also highly disrupted by faults. Only the uppermost reflections that are also parallel show a slightly undulation right over the anticline between 10 to $50 \mathrm{~m}$ of horizontal distance.

The proposed interpretation is that the undulating reflections described here record sediment defor- 


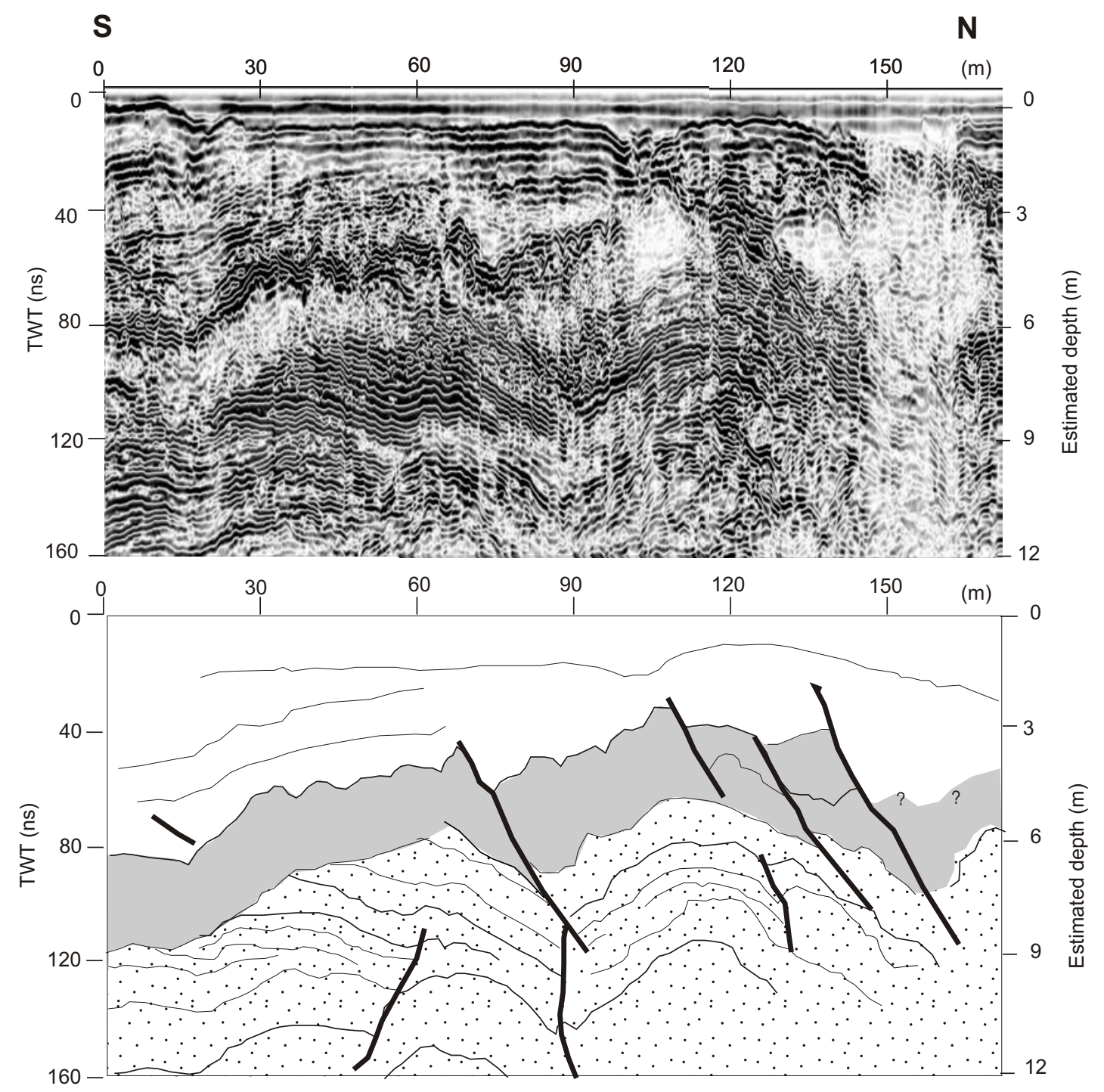

Fig. 7 - GPR (upper) and line drawing (lower) of a section from the Atalaia Beach showing Miocene deposits (dotted and toned intervals) strongly deformed by folds and steeply-dipping normal faults, respectively.

mation that would have taken place sometime during the Miocene. To release the stress during folding, the beds were locally disrupted by faults and fractures, as revealed by the presence of features similar to the ones described in the two previous figures.

\section{CONCLUDING DISCUSSION}

Although the Neogene deposits in northeastern Pará State appear to be preferentially horizontal in the outcrops, bed distortion reveals to be locally significant, recording strata deformation, as interpreted by the presence of numerous fractures and faults (normal and minor reverse), associated with open anticlines and synclines. Field observations previously made in this study area had already led to the recognition of fractures and folds in the Neogene succession, though they were first attributed to syn-depositional soft sediment deformation caused by natural instabilities in the depositional system. 


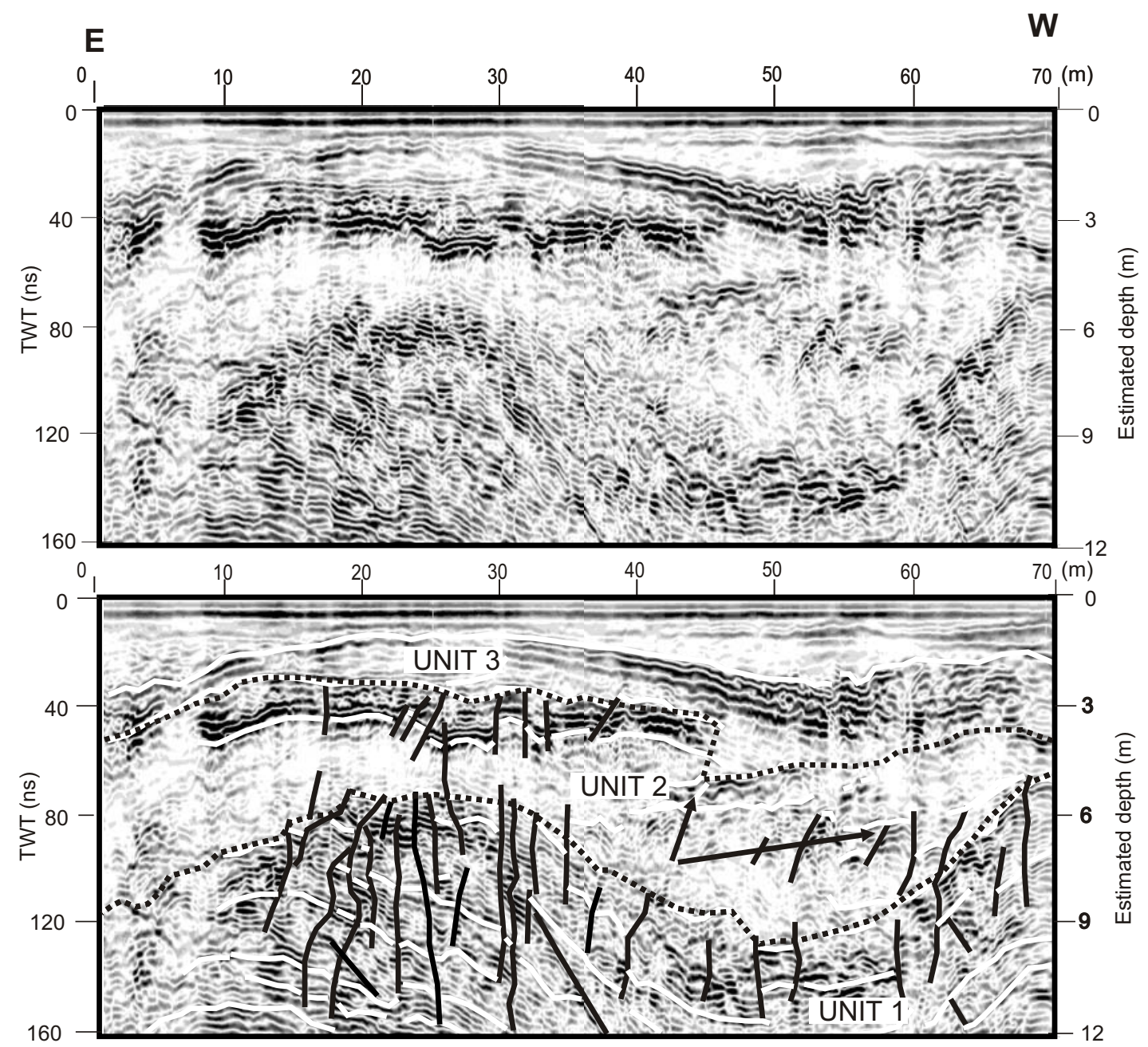

Fig. 8 - Non-annotated (upper) and interpreted (lower) GPR sections from the Atalaia Beach, showing a strongly deformed horizon at the base, forming two anticlines with an associated syncline (unit 1). The anticline apex shows numerous faults and fractures (indicated by the black vertical to inclined lines). Some of these continue upward into unit 2, but do not affect the youngest strata of unit 3 . In particular the parallel reflections over the anticline to the left is strongly disrupted by normal and reverse faults. The white continuous lines indicate pronounced beds. The white dotted lines show the interpreted discontinuity surfaces that mark unit boundaries. The arrows point to places where beds on unit 2 could have been strongly disrupted by faults. See text for further explanations.

However, the data presented here allows to clearly state that tectonics had a strong control on the local deformation of these deposits. These data conform to structural studies, which have proposed a complex evolution for this area, including the development of sets of NW/SE and NNW/SSE-oriented normal faults cut by NE/SW and E/W-oriented strike-slip faults (Igreja et al. 1990, Costa et al. 2001).
Analysis of the available GPR data revealed that deformation features, particularly expressive in deposits of Miocene age, rapidly decreased upward in the post-Barreiras sediments. This indicates a main deformation phase taking place after formation of the Miocene deposits, but before the PlioPleistocene. Deformation involved normal and, to a less extend, reverse faults, fractures, and folds, in- 
dicating compression. The deformation structures interpreted in the GPR sections are consistent with strike-slip regime, as proposed for the study area. Areas with strike-slip deformation are characterized by the co-existence of folds and faults with normal and reverse separation, as a reflex of simultaneous shortening and extension (Christie-Blick and Biddle 1985). Zones experiencing extension may display gaps in surface ruptures, which could have produced depositional sites for the Plio-Pleistocene strata during strike-slip tectonism. Tectonics might have also been the main mechanism to create space and accommodate the post-Miocene deposits, as revealed by the presence of thicker deposits of this age in subsiding areas where faults were more pronounced. Therefore, the features recorded here are highly expected considering the structural style proposed to the study area.

Considering the data recorded in this paper, it is concluded that the GPR might be an important tool to help prospecting and analyzing shallow features in the Neogene deposits of northeastern Pará State. This procedure might significantly contribute to provide additional field data to improve the tectonic models available in this area.

\section{ACKNOWLEDGMENTS}

This work was supported by a grant from the CNPq (PNPPG/2000). For logistical support, the author is grateful to the Goeldi Museum. Special thanks are due to Cláudia Cristina de Melo, Heloísa Maria Santos, Lena Barata e Leandro Miranda for the assistance with the equipment operation during the fieldwork.

\section{RESUMO}

A caracterização geológica de depósitos neógenos ocorrentes em sub-superfície rasa no nordeste do Estado do Pará, usando Radar de Penetração no Solo (GPR), revelou a presença de falhas normais e reversas, bem como dobras, ainda não documentadas em estudos de campo prévios. As falhas são identificadas por reflexões inclinadas que cortam bruscamente reflexões vizinhas, causando freqüentes deslocamentos de camadas. As dobras são reconhecidas por reflexões fortemente ondulantes, configurando feições côncavas e convexas que medem até $50 \mathrm{~m}$ de amplitude e 80 a $90 \mathrm{~m}$ de profundidade. Estas estruturas deformacionais desenvolvem-se, principalmente, em depósitos de idade miocênica, embora algumas falhas possam estender-se, também, a depósitos mais jovens. Embora as seções de GPR estudadas mostrem várias difrações causadas por árvores, umidade do solo, e objetos enterrados, as estruturas registradas aqui não podem ser explicadas por nenhum destes "ruídos". A análise detalhada das seções de GPR revelou que as feições deformacionais estudadas estão relacionadas com distorções de camadas causadas por deformações rúptil e dúctil. Embora falhas e dobras não sejam amplamente registradas em depósitos neógenos da Zona Bragantina, os dados aqui apresentados são consistentes com modelos estruturais, que propõem uma evolução complexa incluindo movimentações transcorrentes para esta área, do Mioceno até o presente.

Palavras-chave: Neógeno, nordeste do Estado do Pará, Radar de Penetração no Solo, tectônica, rochas sedimentares.

\section{REFERENCES}

ACKermann FL. 1964. Geologia e fisiografia da região Bragantina-Estado do Pará. Cadernos da Amazônia 21: $1-90$.

AsPRION U. 1998. Ground-penetrating radar (GPR) analysis in aquifer-sedimentology: case studies, with an emphasis on glacial systems of SW Germany. Tübinger Geowissenschaftliche Arbeiten 43: 1-105.

Bano M, Marquis G, Niviére B, Maurin JC and Cushing M. 2000. Investigating alluvial and tectonic features with ground-penetrating radar and analyzing diffractions patterns. J Applied Geophysics 43: 33-41.

Bridge JS, Alexander J, Collier REL, Gawthorpe RL AND JARVIS J. 1995. Ground-penetrating radar and coring used to study the large-scale structure of point-bar deposits in three dimensions. Sedimentology 42: 839-852.

BRISTOw C. 1995. Facies analysis in the Lower Greensand using ground-penetrating radar. J Geol Soc Lon- 
don 152: 591-598.

Busby JP ANd MerRitt JW. 1999. Quaternary deformation mapping with ground penetrating radar. $\mathbf{J}$ Applied Geophysics 41: 75-91.

Christie-Blick N and Biddle KT. 1985. Deformation and basin formation along strike-slip faults. In: KT Biddle ANd N Christie-Blick (Eds.), Strikeslip deformation, basin formation, and sedimentation, S.E.P.M. Special Publication 37: 1-34.

Costa JBS, Borges MS, Bemerguy RL, FernanDes JMG, Costa Júnior PS AND Costa ML. 1993. Evolução cenozóica da região de Salinópolis, nordeste do Estado do Pará. Bol Geoc USP, 12: 373-396.

Costa JBS, Memerguy RL, Hasui Y and Borges MS. 2001. Tectonics and paleogeography along the Amazon river. J South American Earth Sci 14: 335-347.

Dagallier G, Laitinen AI, Malartre F, Van CampENHOUT IPAM AND VeEkEN PCH. 2000. Groundpenetrating radar: application in a shallow marine Oxfordian limestone sequence located on the eastern flank of the Paris Basin, NE France. Sed Geol 130: 149-165.

Fisher E, McMechan GA and Annan AP. 1992. Acquisition and processing of wide-aperture ground penetrating radar data. Geophysics, 57: 495-504.

Igreja HLS, Borges MS, Alves RJ, Costa Júnior PSC AND Costa JBS. 1990. Estudos neotectônicos nas Ilhas de Outeiro e Mosqueiro, NE do Estado do Pará. In: Congresso Brasileiro de Geologia, 36. Natal. Anais, Natal: SBG, 1990, 5: 2110-2123.

Katzer G. 1933. Geologia do Estado do Pará (Brasil). Bol Mus Par Emílio Goeldi Hist Nat Etnog 9: 1-269.

Meschede M, Asprion U and Reicherter K. 1997. Visualization of tectonic structures in shallow-depth high-resolution Ground Penetrating Radar (GPR) profiles. Terra Nova 9: 167-170.

Moffat DL and Puskar RJ. 1976. A subsurface electromagnetic pulse radar. Geophysics 41: 506-518.

OvergaArd T And Jakobsen PR. 2001. Mapping of glaciotectonic deformation in an ice marginal environment with ground penetrating radar. J Applied Geophysics 47: 191-197.

Roberts R, Daniels JL and Vendl M. 1991. Seasonal variations and ground penetrating radar repeatability.
In: Annual Meeting of the Society for ExploRAtion Geophysicists, 61. Tulsa. Abstract Book, Tulsa: Soc Exploration Geophysicists 1: 486-489.

RossEtTi DF. 2000. Influence of low amplitude/high frequency relative sea-level changes in a wavedominated estuary (Miocene), São Luís Basin, northern Brazil. Sed Geol 133: 295-324.

Rossetti DF. 2001. Late Cenozoic sedimentary evolution in northeastern Pará, within the context of sea level changes. J South Am Earth Sci 14: 77-89.

Rossetti DF AND Góes AM. 2001a. Ground Penetrating Radar: Application in Cenozoic Deposits at the Outeiro Island, PA. In: Simpósio DE Geologia da Amazônia, 7. Belém. CD-ROM..., Belém: SBG, 2001.

Rossetti DF AND GóEs AM. 2001b. Análise rasa de subsuperfície na Praia do Atalaia, município de Salinópolis (PA), com radar de penetração no solo. In: Simpósio de Geologia da Amazônia, 7. Belém. CD-ROM, Belém: SBG, 2001.

Rossetti DF AND Góes AM. 2001c. Imaging Upper Tertiary to Quaternary deposits from northern Brazil applying ground penetrating radar. Rev Bras Geoc 31: $195-202$.

Rossetti DF, Truckenbrodt W and Góes AM. 1989. Estudo paleoambiental e estratigráfico dos Sedimentos Barreiras e Pós-Barreiras na região Bragantina, nordeste do Pará. Bol Mus Paraense Emílio Goeldi, Sér Ciênc Terra 1: 25-74.

Rossetti DF, Góes AM And Truckenbrodt W. 1990. A influência marinha nos Sedimentos Barreiras. Bol Mus Paraense Emílio Goeldi, Sér Ciênc Terra 2: $17-29$.

Rossetti DF, GóEs AM AND Souza LSB. 2003. Estratigrafia da sucessão sedimentar Pós-Barreiras (Zona Bragantina, Pará) com base em radar de penetração no solo. Rev Bras Geof. In press.

Smith DG AND Jol HM. 1995. Wasatch Fault (Utah), detected and displacement characterized by ground penetrating radar. Environ Eng Geosci 1: 489-496.

StePhens M. 1994. Architectural element analysis within the Kayenta Formation (Lower Jurassic) using ground-probing radar and sedimentological profiling, southwestern Colorado. Sed Geol 90: 179-211.

Stevens KM, Lodha GS, Holloway AL and Soon- 
AWALA NM. 1995. The application of ground penetrating radar for mapping fractures in plutonic rocks within the Whiteshell Research Area, Pinawa, Manitoba, Canada. J Applied Geophysics 33: 125-141.

Toshioka T, Tsuchida T and Sasahara K. 1995. Application of GPR to detecting and mapping cracks in rock slopes. J Applied Geophysics 33: 119-124.
Van Heteren S, Fitzgerald DM, McKinlay PA and BuYNEVICH IV. 1998. Radar facies of paraglacial barrier systems: coastal New England, USA. Sedimentology 45: 181-200.

Wyatt DE and Temples TJ. 1996. Ground-penetrating radar detection of small-scale channels, joints and faults in the unconsolidated sediments of the Atlantic Coastal Plain. Environmental Geology 27: 219-225. 